\title{
Effects of health insurance on patient demand for physician services
}

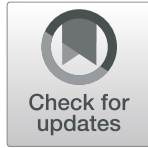

Jerome Dugan(1)

\begin{abstract}
Background: In recent years, policymakers have sought to reduce health disparities between the insured and uninsured through a federal health insurance expansion policy; however, disparities continue to persist among the insured population. One potential explanation is that the use of healthcare services varies by the type of health insurance coverage due to differences in the design of coverage. The aim of this study is to examine whether health insurance coverage type is associated with the structure and use of healthcare services.

Methods: The nationally representative Medical Expenditure Panel Survey and multinomial logistic regression are used to estimate the effects of different types of health coverage on the combinations of routine and emergency care sought and received.

Results: The multinomial logistic regression analysis for the overall sample revealed privately insured respondents reported higher use of routine care only $p<0.01$ and lower use of emergency room care only $(-2.13 \% ; p<0.01)$ than the uninsured. The publicly insured reported similar trends for use of routine care only $(17.93 \% ; p<0.01)$ as the privately insured, as compared to the uninsured. Both the privately and publicly insured reported higher use of a mixture of care; however, publicly insured were more likely to use a mixture of care $(8.57 \%, p<0.01)$.

Conclusion: The results show that health insurance is associated with higher use of the physician services, but does not promote the use of cost-effective schedules of care among the publicly insured.
\end{abstract}

Keywords: Healthcare management, Chronic disease, Health insurance

\section{Introduction}

The Social Security Act Amendments (Pub L N. 89-97), passed in 1965, were designed to address the low rates of insurance among financially vulnerable households not receiving coverage from an employer by creating the Medicare insurance program for older adults over 65 and the Medicaid insurance program for low income mothers and children. However, in later years, coverage expansions have widened to include the remainder of the uninsured population using both a public and private mechanism. More specifically, the Affordable Care Act

Correspondence: jad19@uw.edu

Department of Health Services, School of Public Health, University of Washington, 1959 NE Pacific St Magnuson Health Sciences Center, Room H-680, Box 357660, Seattle, WA 98195-7660, USA
(Pub L N. 111-148) reduced the uninsured rate across the population by allowing states to expand Medicaid to include low-income adults, providing premium subsidies to help improve the affordability of private health plans, and imposing an individual mandate requiring all persons not receiving government or employer-based insurance to retain coverage. The most recent expansion policies under the ACA were able to lower the uninsured rate among non-elderly population from 46.5 million to 27.4 million between 2010 and 2017, thus highlighting the strength of using either a public or private insurance as a mechanism to address the uninsured rate and number of uninsured.

In the next round of reforms, policymakers are debating whether to move forward with a public takeover of 
the U.S. healthcare insurance system or alternatively push for a tiered set of private healthcare plans to cover the remainder of the uninsured population. Researchers in the US have documented that insurance status plays an important role in individual health, as the uninsured are the least likely to use preventative medical services, are the most likely to encounter financial barriers to access care, and report the highest rates of preventable hospitalizations [1-7]; however, less is known about how use of care varies by health insurance coverage type (e.g., no insurance, public insurance, private insurance). This paper aims to examine how the structure and scope of medical services sought and received vary by insurance status.

\section{Methods}

\section{Sources of data}

The Medical Expenditure Panel Survey (MEPS) provides the most current and comprehensive individual-level data for evaluating medical consumption, expenditure, and health status. This study uses data from the household component of the MEPS, which collects data from a nationally representative subsample of the National Health Interview Survey participants from the previous year. The base year for the study is 2015, the year following the implementation of the ACA's core health insurance expansion provisions, and the final year is 2017, the most recent year that comprehensive data are available. The analysis dataset was restricted to respondents aged 26 to 64 to avoid potential cofounding effects of the young adult health insurance coverage provisions (under age 26) and Medicare (over the age 64).

\section{Outcome measures}

Medical treatment bundles - a group of individual medical services that are used together to manage personal health - are utilized to capture patients' tastes for different patterns of healthcare utilization. In this study, several measures of individual utilization were combined into a single categorical measure of medical treatment. The following three treatment bundles were considered: two or more routine office-based visits only, two or more emergency room visits only, and any mixture of two or more routine or emergency room visits. Respondents also have the option to make one or less medical visits of either kind. It is important to note that medical treatment bundles used in this study do not represent an absolute measure of utilization, but rather, are designed to reveal patterns of utilization.

\section{Control variables}

For our sample of adults aged 26 to 64, respondents were identified as being publicly insured if they were recipients of Medicaid (the state-federal insurance program for low-income and disabled persons or some other state-federally sponsored insurance plan) TRIC ARE (the health care program of the United States Department of Defense Military Health System), or other public hospital/physician programs. To avoid the potential confounding effects of Social Security Insurance (SSI) and Social Insurance Disability (SSD), programs that provide both cash assistance and Medicare to individuals with a qualified disability status, Medicare beneficiaries are excluded. Respondents were identified as being privately insured if they obtained their coverage from their employer or a private health insurance marketplace. Respondents who report no private or public insurance coverage were identified as being uninsured. In addition to controlling for health insurance coverage type, a number of socioeconomic variables to reduce confounding bias are included. Socioeconomic control variables included age, sex, race/ethnicity, educational attainment, personal income. Census region and survey year were also included in the regression analysis to control for geographic and time effects.

\section{Statistical analysis}

This study utilizes a discrete choice framework, where the choice set is defined by set of medical treatment bundles and the decision makers are patients with different health insurance coverage statuses [8-10]. Conditioned on a coverage type, a patient's optimization problem is to select the medical treatment bundle that minimizes their risk of an acute event subject to the constraints imposed by their individual health insurance status. Empirical estimation for this optimization problem is performed using multinomial logistic regression (MLR) $[10,11]$, which models the probability that patient will choose a given medical treatment bundle over an alternative bundle. The MLR coefficients have been converted from odds ratios into marginal effects to improve the interpretability of results. All regressions are weighted to adjust for oversampling and include robust standard errors to address heteroskedastic bias. The theoretical and empirical model is described in more detail in Appendix A.

\section{Results \\ Summary statistics}

Population-weighted socioeconomic characteristics of respondents aged 26 to 64 for the overall study population are described in Table 1, Column 1. For the overall sample $(n=47,252)$, the mean age was 44.46 years, and $51.21 \%$ of the population were men. Respondents with private insurance represent $77.44 \%$ of the sample, respondents with public insurance represent $11.34 \%$ of the sample, and uninsured respondents represent $11.21 \%$ of the sample. All major racial groups are well represented 
Table 1 Descriptive Statistics of Adults by Medical Treatment Bundle

\begin{tabular}{|c|c|c|c|c|c|c|}
\hline Characteristics & All & $\begin{array}{l}\text { Routine } \\
\text { Visits Only }\end{array}$ & $\begin{array}{l}\text { Emergency } \\
\text { Visits Only }\end{array}$ & $\begin{array}{l}\text { Mixture } \\
\text { of Visits }\end{array}$ & $\begin{array}{l}\text { One or Less } \\
\text { Visits }\end{array}$ & $x^{2} P$ \\
\hline & (1) & (2) & (3) & (4) & (4) & (5) \\
\hline Unweighted sample size, $N$ & 47,252 & 22,454 & 1378 & 4530 & 18,890 & \\
\hline Mean age, y & $\begin{array}{l}44.46 \\
(11.26)\end{array}$ & $\begin{array}{l}46.21 \\
(11.21)\end{array}$ & $\begin{array}{l}40.92 \\
(10.45)\end{array}$ & $\begin{array}{l}45.59 \\
(11.39)\end{array}$ & $\begin{array}{l}41.84 \\
(10.80)\end{array}$ & $<0.01$ \\
\hline \multicolumn{7}{|l|}{ Gender } \\
\hline Female, \% & $\begin{array}{l}48.79 \\
(49.99)\end{array}$ & $\begin{array}{l}42.69 \\
(49.46)\end{array}$ & $\begin{array}{l}53.50 \\
(49.90)\end{array}$ & $\begin{array}{l}37.41 \\
(48.39)\end{array}$ & $\begin{array}{l}60.36 \\
(48.92)\end{array}$ & $<0.01$ \\
\hline Male, \% & $\begin{array}{l}51.21 \\
(49.99)\end{array}$ & $\begin{array}{l}57.31 \\
(49.46)\end{array}$ & $\begin{array}{l}46.50 \\
(49.90)\end{array}$ & $\begin{array}{l}62.59 \\
(48.39)\end{array}$ & $\begin{array}{l}39.64 \\
(48.92)\end{array}$ & $<0.01$ \\
\hline \multicolumn{7}{|l|}{ Geographic Region } \\
\hline Northeast, \% & $\begin{array}{l}17.66 \\
(38.14)\end{array}$ & $\begin{array}{l}18.78 \\
(39.06)\end{array}$ & $\begin{array}{l}15.44 \\
(36.14)\end{array}$ & $\begin{array}{l}18.34 \\
(38.70)\end{array}$ & $\begin{array}{l}16.00 \\
(36.66)\end{array}$ & $<0.01$ \\
\hline Midwest, \% & $\begin{array}{l}20.81 \\
(40.60)\end{array}$ & $\begin{array}{l}21.01 \\
(40.74)\end{array}$ & $\begin{array}{l}22.23 \\
(41.60)\end{array}$ & $\begin{array}{l}23.29 \\
(42.27)\end{array}$ & $\begin{array}{l}19.78 \\
(39.84)\end{array}$ & $<0.01$ \\
\hline South, \% & $\begin{array}{l}37.34 \\
(48.37)\end{array}$ & $\begin{array}{l}36.33 \\
(48.10)\end{array}$ & $\begin{array}{l}42.70 \\
(49.48)\end{array}$ & $\begin{array}{l}38.09 \\
(48.57)\end{array}$ & $\begin{array}{l}38.26 \\
(48.60)\end{array}$ & $<0.01$ \\
\hline West, \% & $\begin{array}{l}24.18 \\
(42.82)\end{array}$ & $\begin{array}{l}23.87 \\
(42.63)\end{array}$ & $\begin{array}{l}19.63 \\
(39.74)\end{array}$ & $\begin{array}{l}20.28 \\
(40.21)\end{array}$ & $\begin{array}{l}25.96 \\
(43.84)\end{array}$ & $<0.01$ \\
\hline \multicolumn{7}{|l|}{ Insurance Coverage } \\
\hline Private insurance, \% & $\begin{array}{l}77.44 \\
(41.80)\end{array}$ & $\begin{array}{l}84.96 \\
(35.74)\end{array}$ & $\begin{array}{l}54.88 \\
(49.78)\end{array}$ & $\begin{array}{l}69.83 \\
(45.90)\end{array}$ & $\begin{array}{l}69.96 \\
(45.85)\end{array}$ & $<0.01$ \\
\hline Public insurance, $\%$ & $\begin{array}{l}11.34 \\
(31.71)\end{array}$ & $\begin{array}{l}9.59 \\
(29.44)\end{array}$ & $\begin{array}{l}24.37 \\
(42.95)\end{array}$ & $\begin{array}{l}23.25 \\
(4224)\end{array}$ & $\begin{array}{l}9.93 \\
(29.91)\end{array}$ & $<0.01$ \\
\hline Uninsured, \% & $\begin{array}{l}11.21 \\
(31.56)\end{array}$ & $\begin{array}{l}5.45 \\
(22.70)\end{array}$ & $\begin{array}{l}20.75 \\
(40.57)\end{array}$ & $\begin{array}{l}6.922 \\
(25.39)\end{array}$ & $\begin{array}{l}20.11 \\
(40.09)\end{array}$ & $<0.01$ \\
\hline \multicolumn{7}{|l|}{ Race/Ethnicity } \\
\hline White non-Hispanic, \% & $\begin{array}{l}61.37 \\
(48.69)\end{array}$ & $\begin{array}{l}66.11 \\
(47.34)\end{array}$ & $\begin{array}{l}52.24 \\
(49.97)\end{array}$ & $\begin{array}{l}62.16 \\
(48.50)\end{array}$ & $\begin{array}{l}54.86 \\
(49.76)\end{array}$ & $<0.01$ \\
\hline Black non-Hispanic, \% & $\begin{array}{l}11.93 \\
(32.41)\end{array}$ & $\begin{array}{l}10.43 \\
(30.56)\end{array}$ & $\begin{array}{l}20.32 \\
(40.25)\end{array}$ & $\begin{array}{l}15.72 \\
(36.40)\end{array}$ & $\begin{array}{l}12.57 \\
(33.15)\end{array}$ & $<0.01$ \\
\hline Other non-Hispanic, \% & $\begin{array}{l}9.36 \\
(29.12)\end{array}$ & $\begin{array}{l}9.15 \\
(28.82)\end{array}$ & $\begin{array}{l}8.17 \\
(27.39)\end{array}$ & $\begin{array}{l}6.89 \\
(25.33)\end{array}$ & $\begin{array}{l}10.39 \\
(30.51)\end{array}$ & $<0.01$ \\
\hline Hispanic, \% & $\begin{array}{l}17.34 \\
(37.86)\end{array}$ & $\begin{array}{l}14.31 \\
(35.03)\end{array}$ & $\begin{array}{l}19.27 \\
(39.46)\end{array}$ & $\begin{array}{l}15.24 \\
(35.94)\end{array}$ & $\begin{array}{l}22.18 \\
(41.55)\end{array}$ & $<0.01$ \\
\hline \multicolumn{7}{|l|}{ Educational Attainment } \\
\hline No degree & $\begin{array}{l}10.11 \\
(30.15)\end{array}$ & $\begin{array}{l}7.52 \\
(26.38)\end{array}$ & $\begin{array}{l}17.61 \\
(38.11)\end{array}$ & $\begin{array}{l}12.20 \\
(32.73)\end{array}$ & $\begin{array}{l}12.86 \\
(33.48)\end{array}$ & $<0.01$ \\
\hline High school degree/GED & $\begin{array}{l}26.59 \\
(44.18)\end{array}$ & $\begin{array}{l}23.38 \\
(42.33)\end{array}$ & $\begin{array}{l}33.69 \\
(47.29)\end{array}$ & $\begin{array}{l}28.49 \\
(45.14)\end{array}$ & $\begin{array}{l}30.31 \\
(45.96)\end{array}$ & $<0.01$ \\
\hline At least some college & $\begin{array}{l}63.30 \\
(48.20)\end{array}$ & $\begin{array}{l}69.09 \\
(46.21)\end{array}$ & $\begin{array}{l}48.70 \\
(50.01)\end{array}$ & $\begin{array}{l}59.31 \\
(49.13)\end{array}$ & $\begin{array}{l}56.83 \\
(49.53)\end{array}$ & $<0.01$ \\
\hline
\end{tabular}

in the sample, with White non-Hispanics, Black nonHispanics, and Hispanics representing 61.37, 11.93, and $17.34 \%$, respectively. High school dropouts represent $10.11 \%$ of the sample, while respondents with a high school degree or at least some college experience represent 26.59 and $63.30 \%$, respectively.

In addition to reporting personal characteristics for the overall sample, Table 1 also reports socioeconomic characteristics of respondents who make two or more routine visits only (Table 1 , Column 2), two or more emergency visits only (Table 1, Column 3), a mixture of two or more routine and emergency visits (Table 1, Column 4), or one or less medical visits of either type (Table 1, Column 5). Medical utilization varied considerably across different medical treatment bundles, with 22, 454 making routine visits only, 1378 making emergency visits only, 4530 making a mixture of visits, and 18,890 making one or less visits. Women are more likely than 
men to make emergency visits only $(53.50 \%)$ or one or less visits $(60.36 \%)$, while men are more likely than women to make routine visits only (57.71\%) and mixture of visits $(62.59 \%)$. White respondents, privately insured respondents, and respondents with at least some college are more likely to make physician visits of any type over all other insurance status, racial/ethnic, and educational attainment groups.

\section{Effects of health insurance coverage type of health care utilization}

The multinomial logistic regression results summarizing the impact of insurance type on a patient's use of office-based visits only, emergency room visits only, and a mixture of visits, as compared to inadequate utilization are reported in Table 2. The results of the overall sample (Panel A) show that adults with private insurance had a higher probability of utilizing routine office-based care $(24.33 \% ; p<0.01)$, a lower probability of using emergency care only $(-2.13 \% ; p<0.01)$, and a high probability to use a mixture of routine and emergency care $(1.27 \% ; p<0.10)$ than the uninsured. Similarly, the overall sample results show that adults with public insurance had a higher probability of utilizing routine care only $(17.93 \% ; p<0.01)$ and a mixture of routine and emergency care $(8.57 \% ; p<$ 0.01) than the uninsured.

In order to understand how the effects of insurance coverage on utilization varies across race/ethnicity, MLR models were also estimated for the three largest racial/ ethnic groups: White non-Hispanics (Table 1, Panel B),
Black non-Hispanics (Table 1, Panel C), and Hispanics (Table 1, Panel C). The racial/ethnic subgroup analysis revealed White non-Hispanics reported similar trends of the overall study population. While Black non-Hispanics and Hispanics also report similar trends as the overall population, Black non-Hispanic respondents with public insurance reported lower use of emergency visits only $(2.00 \% ; p<0.01)$ and publicly insured Hispanics reported a higher use of emergency visits only $(1.44 \% ; p<0.01)$ than uninsured Black non-Hispanics and Hispanics, respectively.

\section{Patterns of healthcare utilization by disease group}

Table 3 also presents the medical treatment regression results for individual diseases, focusing on hypertension respondents (Table 3, Panel A), coronary heart disease and stroke (CHDS) respondents (Table 3, Panel B), diabetes respondents (Table 3, Panel $\mathrm{C}$ ), and cancer respondents (Table 3, Panel D). The purpose of the chronic disease subgroup analysis is to examine the role disease status plays in physician use. Respondents were identified as having hypertension, CHDS, diabetes, or cancer. Respondents were identified as having CHDS if they were ever told by a doctor or other health professional that they had coronary heart disease, a heart attack, or stroke. CHDS patients are organized into a single diagnosis group because both groups share the same pathophysiology [12-14].

The results of the hypertension group (Table 3, Panel A) show that adults with private insurance had a higher probability of utilizing routine office-based care $(18.68 \%$;

Table 2 Medical Treatment Regression Analysis, Multinomial Logistic Regression Analysis

\begin{tabular}{|c|c|c|c|c|c|c|}
\hline & $\begin{array}{l}\text { Routine } \\
\text { Visits Only a }\end{array}$ & $\begin{array}{l}\text { Emergency } \\
\text { Visits Only }\end{array}$ & $\begin{array}{l}\text { Mixture } \\
\text { of Visits }\end{array}$ & $\begin{array}{l}\text { Routine } \\
\text { Visits Only a }\end{array}$ & $\begin{array}{l}\text { Emergency } \\
\text { Visits Only b }\end{array}$ & $\begin{array}{l}\text { Mixture } \\
\text { of Visits }^{c}\end{array}$ \\
\hline \multirow[t]{2}{*}{ Coefficient } & (1) & $(2)$ & (3) & (4) & (5) & (6) \\
\hline & \multicolumn{3}{|c|}{ A. Overall Sample $(N=36,424)$} & \multicolumn{3}{|c|}{ B. White non-Hispanic $(N=15,407)$} \\
\hline Private insurance & $\begin{array}{l}24.33^{* * *} \\
(1.09)\end{array}$ & $\begin{array}{l}-2.13^{* * *} \\
(0.26)\end{array}$ & $\begin{array}{l}1.27^{*} \\
(0.74)\end{array}$ & $\begin{array}{l}27.45^{* * *} \\
(1.93)\end{array}$ & $\begin{array}{l}-2.02^{* * *} \\
(0.37)\end{array}$ & $\begin{array}{l}0.10 \\
(1.15)\end{array}$ \\
\hline Public insurance & $\begin{array}{l}17.93^{* * *} \\
(1.30)\end{array}$ & $\begin{array}{l}0.25 \\
(0.26)\end{array}$ & $\begin{array}{l}8.57^{* * *} \\
(0.76)\end{array}$ & $\begin{array}{l}19.07^{* * *} \\
(2.34)\end{array}$ & $\begin{array}{l}0.09 \\
(0.39)\end{array}$ & $\begin{array}{l}7.19^{* * *} \\
(1.25)\end{array}$ \\
\hline \multirow[t]{2}{*}{ Uninsured } & 1 & 1 & 1 & 1 & 1 & 1 \\
\hline & \multicolumn{3}{|c|}{ C. Black non-Hispanic $(N=6315)$} & \multicolumn{3}{|c|}{ D. Hispanic $(N=10,773)$} \\
\hline Private insurance & $\begin{array}{l}26.36^{* * *} \\
(2.44)\end{array}$ & $\begin{array}{l}-4.90^{* * *} \\
(0.69)\end{array}$ & $\begin{array}{l}2.05 \\
(1.71)\end{array}$ & $\begin{array}{l}19.46^{* * *} \\
(1.45)\end{array}$ & $\begin{array}{l}-1.46^{* * *} \\
(0.46)\end{array}$ & $\begin{array}{l}2.71^{* *} \\
(1.13)\end{array}$ \\
\hline Public insurance & $\begin{array}{l}23.13^{* * *} \\
(2.76)\end{array}$ & $\begin{array}{l}-2.00^{* * *} \\
(0.72)\end{array}$ & $\begin{array}{l}10.10^{* * *} \\
(1.77)\end{array}$ & $\begin{array}{l}13.62 \\
(1.72)\end{array}$ & $\begin{array}{l}1.44^{* * *} \\
(0.48)\end{array}$ & $\begin{array}{l}9.57^{* * *} \\
(1.12)\end{array}$ \\
\hline Uninsured & 1 & 1 & 1 & 1 & 1 & 1 \\
\hline
\end{tabular}

Notes: The multinomial logistic regression coefficients have been converted into marginal effects to improve interpretability. Standard deviations are reported in parentheses. All regressions include individual controls and time trends. The reference category is uninsured respondents

${ }^{a}$ Routine visits only, $2+$ routine office based visits only

${ }^{b}$ Emergency visits only, 2+ emergency room visits only

c Mixture of visits, $2+$ routine and emergency room only

*Significant at $10 \%$ confidence level

**Significant at $5 \%$ confidence level

***Significant at $1 \%$ confidence level 
Table 3 Medical Treatment Regression Analysis, Multinomial Logistic Regression Analysis

\begin{tabular}{|c|c|c|c|c|c|c|}
\hline & $\begin{array}{l}\text { Routine } \\
\text { Visits Only a }\end{array}$ & $\begin{array}{l}\text { Emergency } \\
\text { Visits Only }\end{array}$ & $\begin{array}{l}\text { Mixture } \\
\text { of Visits }\end{array}$ & $\begin{array}{l}\text { Routine } \\
\text { Visits Only a }\end{array}$ & $\begin{array}{l}\text { Emergency } \\
\text { Visits Only }\end{array}$ & $\begin{array}{l}\text { Mixture } \\
\text { of Visits }^{c}\end{array}$ \\
\hline \multirow[t]{2}{*}{ Coefficient } & (1) & (2) & (3) & (4) & (5) & (6) \\
\hline & \multicolumn{3}{|c|}{ A. Hypertension $(N=10,425)$} & \multicolumn{3}{|c|}{ B. $C H D S(N=3759)$} \\
\hline Private insurance & $\begin{array}{l}18.68^{* * *} \\
(1.52)\end{array}$ & $\begin{array}{l}-3.09^{* * *} \\
(0.45)\end{array}$ & $\begin{array}{l}0.68 \\
(1.25)\end{array}$ & $\begin{array}{l}16.04^{* * *} \\
(2.73)\end{array}$ & $\begin{array}{l}-3.80^{* * *} \\
(0.85)\end{array}$ & $\begin{array}{l}1.33 \\
(2.44)\end{array}$ \\
\hline Public insurance & $\begin{array}{l}10.66^{* * *} \\
(1.75)\end{array}$ & $\begin{array}{l}-0.88^{* *} \\
(0.44)\end{array}$ & $\begin{array}{l}12.86^{* * *} \\
(1.27)\end{array}$ & $\begin{array}{l}5.92^{* *} \\
(3.00)\end{array}$ & $\begin{array}{l}-1.40^{*} \\
(0.74)\end{array}$ & $\begin{array}{l}16.04^{* * *} \\
(2.47)\end{array}$ \\
\hline \multirow[t]{2}{*}{ Uninsured } & 1 & 1 & 1 & 1 & 1 & 1 \\
\hline & \multicolumn{3}{|c|}{ C. Diabetes Mellitus ( $N=2945)$} & \multicolumn{3}{|c|}{ D. Cancer $(N=2013)$} \\
\hline Private insurance & $\begin{array}{l}11.18^{* * *} \\
(2.76)\end{array}$ & $\begin{array}{l}-1.83^{* *} \\
(0.77)\end{array}$ & $\begin{array}{l}-2.02 \\
(2.46)\end{array}$ & $\begin{array}{l}14.19 * * * \\
(4.20)\end{array}$ & $\begin{array}{l}-2.33^{* * *} \\
(0.86)\end{array}$ & $\begin{array}{l}-0.69 \\
(3.70)\end{array}$ \\
\hline Public insurance & $\begin{array}{l}-0.07 \\
(3.04)\end{array}$ & $\begin{array}{l}-0.70 \\
(0.75)\end{array}$ & $\begin{array}{l}13.92^{* * *} \\
(2.47)\end{array}$ & $\begin{array}{l}5.29 \\
(4.68)\end{array}$ & $\begin{array}{l}-1.85^{* *} \\
(0.93)\end{array}$ & $\begin{array}{l}11.96^{* * *} \\
(3.85)\end{array}$ \\
\hline Uninsured & 1 & 1 & 1 & 1 & 1 & 1 \\
\hline \multicolumn{7}{|c|}{$\begin{array}{l}\text { Notes: The multinomial logistic regression coefficients hav } \\
\text { parentheses. All regressions include individual controls an } \\
\text { and stroke } \\
\text { a Routine visits only, } 2+\text { routine office based visits only } \\
\text { b Emergency visits only, } 2+\text { emergency room visits only } \\
\text { " Mixture of visits, } 2+\text { routine and emergency room only } \\
{ }^{*} \text { Significant at } 10 \% \text { confidence level } \\
\text { **Significant at } 5 \% \text { confidence level } \\
\text { ** Significant at } 1 \% \text { confidence level }\end{array}$} \\
\hline
\end{tabular}

$p<0.01)$ and a lower probability of using emergency care only $(-3.09 \% ; p<0.01)$ than the uninsured. Private insurance was not associated with an increased propensity of using a mixture of routine and emergency room care. Similarly, adults with public insurance had a higher probability of utilizing routine care only (10.66\%; $p<0.01)$ and less likely to utilize emergency care only $(-0.88 \% ; p=0.096)$ than the uninsured. Although adults with private and public insurance are more likely to use a mixture of routine and emergency care than the uninsured, patients with public insurance reported a substantially higher probability to use a mixture of routine and emergency care $(18.41 \% ; p<0.01)$ than the uninsured. The results for the CHDS, diabetes, and cancer groups are consistent with the hypertension group results in sign and magnitude.

\section{Alternative specifications}

In the theoretical framework of this paper (Appendix A), it was argued that if an individual does not consume a treatment bundle in J, then their posttreatment health state is equal to their pre-treatment health state [15]. Because the emergency room setting alone is not the appropriate place for all healthcare needs (e.g., prescription filling), it may be unlikely that emergency only is capable of helping maintain health status. To address this concern, the main analysis is re-estimated without an emergency only medical treatment bundle (Table 4, Panel A). The regression results from this alternative model are similar in sign and magnitude as the regression results of the main model. Second, following the passage of the ACA, income played an important role in determining the amount of government support individual households received to access health insurance: households making less than 133\% FPL are eligible for Medicaid, households making between 133 and $400 \%$ FPL qualify for a premium tax credit, and households making over $400 \%$ FPL receive no ACA related support. To examine the differential impact of government support, the analysis is re-estimated for three income categories (Table 4, Panels B, C, D). The coefficient estimates from the income analysis are consentient with the trends of the overall population.

\section{Addressing endogeneity and omitted variables bias}

A major assumption of the analysis is that coverage status is not endogenously related to use of medical treatment bundles; however, this assumption could be violated if persons select their coverage in anticipation of future healthcare needs. Furthermore, the construction of public and private insurance as uniform health insurance plan types ignores the potential role of non-price rationing across plan types and the mechanism of enrollment (i.e., adverse selection) into health insurance plans can confound any estimates of the effects of coverage on medical treatment. To investigate these issues, the exogenous variation in the timing of acute health events and an age-based 
Table 4 Alternative Specifications, Multinomial Logistic Regression Analysis

\begin{tabular}{|c|c|c|c|c|c|c|}
\hline & $\begin{array}{l}\text { Routine } \\
\text { Visits Only }\end{array}$ & $\begin{array}{l}\text { Emergency } \\
\text { Visits Only }\end{array}$ & $\begin{array}{l}\text { Mixture } \\
\text { of Visits }^{c}\end{array}$ & $\begin{array}{l}\text { Routine } \\
\text { Visits Only }\end{array}$ & $\begin{array}{l}\text { Emergency } \\
\text { Visits Only }\end{array}$ & $\begin{array}{l}\text { Mixture } \\
\text { of Visits }{ }^{c}\end{array}$ \\
\hline \multirow[t]{2}{*}{ Coefficient } & (1) & (2) & (3) & (4) & (5) & (6) \\
\hline & \multicolumn{3}{|c|}{ A. Emergency Visits Only Added to Other Category $(N=36,424)$} & \multicolumn{3}{|c|}{ B. $\leq 133 \% \mathrm{FPL}(N=7707)$} \\
\hline Private insurance & $\begin{array}{l}2.43^{* * *} \\
(1.1)\end{array}$ & & $\begin{array}{l}1.3^{*} \\
(0.7)\end{array}$ & $\begin{array}{l}21.2^{* * *} \\
(2.1)\end{array}$ & $\begin{array}{l}-4.2^{* * *} \\
(1.1)\end{array}$ & $\begin{array}{l}3.2^{*} \\
(1.9)\end{array}$ \\
\hline Public insurance & $\begin{array}{l}1.73^{* * *} \\
(1.3)\end{array}$ & & $\begin{array}{l}8.5^{* * *} \\
(0.8)\end{array}$ & $\begin{array}{l}19.4^{* * *} \\
(1.9)\end{array}$ & $\begin{array}{l}-1.1 \\
(0.7)\end{array}$ & $\begin{array}{l}12.5^{* * *} \\
(1.6)\end{array}$ \\
\hline \multirow[t]{2}{*}{ Uninsured } & 1 & 1 & 1 & 1 & 1 & 1 \\
\hline & \multicolumn{3}{|c|}{ C. 133 to $400 \%$ FPL $(N=15,466)$} & \multicolumn{3}{|c|}{ D. $>400 \%$ FPL $(N=13,251)$} \\
\hline Private insurance & $\begin{array}{l}21.8^{* * *} \\
(1.5)\end{array}$ & $\begin{array}{l}-1.3^{* * *} \\
(0.4)\end{array}$ & $\begin{array}{l}0.025^{* *} \\
(1.1)\end{array}$ & $\begin{array}{l}0.205^{* * *} \\
(0.026)\end{array}$ & $\begin{array}{l}-1.3^{* * *} \\
(0.3)\end{array}$ & $\begin{array}{l}2.5 \\
(1.6)\end{array}$ \\
\hline Public insurance & $\begin{array}{l}14.2^{* * *} \\
(2.0)\end{array}$ & $\begin{array}{l}0.9^{*} \\
(0.5)\end{array}$ & $\begin{array}{l}8.3^{* * *} \\
(1.2)\end{array}$ & $\begin{array}{l}16.9^{* * *} \\
(4.4)\end{array}$ & $\begin{array}{l}-0.5 \\
(0.7)\end{array}$ & $\begin{array}{l}4.0^{*} \\
(2.2)\end{array}$ \\
\hline Uninsured & 1 & 1 & 1 & 1 & 1 & 1 \\
\hline
\end{tabular}

Notes: The multinomial logistic regression coefficients have been converted into marginal effects to improve interpretability. Standard deviations are reported in parentheses. All regressions include individual controls and time trends. The reference category is uninsured respondents. FPL, federal poverty level

${ }^{a}$ Routine visits only, $2+$ routine office based visits only

b Emergency visits only, 2+ emergency room visits only

${ }^{c}$ Mixture of visits, $2+$ routine and emergency room only

* Significant at $10 \%$ confidence level

** Significant at $5 \%$ confidence level

${ }^{* *}$ Significant at $1 \%$ confidence level

eligibility threshold are utilized to address potential endogeneity. Furthermore, omitted variables bias is addressed by controlling for additional coverage characteristics of health insurance plans.

First, the main results are re-estimated using a sample limited to respondents who experienced an acute event/diagnosis (e.g., stroke, heart attack, cancer) within 1 year of being surveyed (Table 5 , Panel A). The results are robust to this sampling restriction. Second, following [13], an RD model that exploits a sharp increase in coverage resulting from older adults becoming eligible for Medicare at age 65 is estimated (Table 5, Panel B). The results of the RD analysis are consistent with the main results, where public insurance respondents are more likely than the uninsured to make routine visits only. Third, additional attributes to public and private insurance are considered by incorporating managed care interaction effects for both public and private plans (Table 5, Panel C). The results of managed care analysis revealed no statistically significant managed care interaction effects.

As health insurance plans vary significantly within public and private insurance groups, the public/private insurance groups are decomposed into specific plan types (Table 5, Panel D). Three types of public, non-Medicare insurance plans (i.e., Medicaid, TRIC ARE/CHAMPVA, other public insurance) and three types of private insurance plans (i.e., job-based group insurance, other group insurance, non-group insurance) are examined in the health insurance attribute analysis. Regarding routine visits only, with an exception to TRICARE/CHAMPVA, all other insurance types reported a higher propensity to make routine visits only as compared to the uninsured. Regarding emergency visits only, among the privately insured, only persons with job-based group insurance reported a lower propensity to make emergency visits only $(-2.16 \% ; p<0.01)$. Among the publicly insured, Medicaid and TRICARE were more likely to make emergency room visits only at $(0.48 \% ; p<0.05)$ and $(1.05 \% ; p<0.10)$, respectively. Persons with other public insurance reported a lower propensity to make emergency visits only $(-5.26 \% ; p<0.05)$. Pubic insurance beneficiaries of any type reported no differences in mixtures of visits; however, Medicaid and TRIC ARE beneficiaries reported a higher propensity to make a mixture of visits at $(7.89 \% ; p<0.01)$ and $(2.58 \% ; p<0.05)$, respectively. The robust findings across all alternative specifications suggest that coverage status is not endogenous to medical treatment bundle choice.

\section{Discussion}

The medical treatment analysis revealed two important results. First, the main results show that the uninsured utilize emergency services at higher rates than the insured and utilize routine office-based services at lower rates than the insured, which is consistent with the literature [1, 2]. Uninsured households face significant non-price rationing related barriers that limit their ability to access routine services, leading this group to seek care in the emergency room setting [16]. Unfortunately, 
Table 5 Addressing Endogeneity and Omitted Variables Bias, Multinomial Logistic Regression Analysis

\begin{tabular}{|c|c|c|c|c|c|c|}
\hline & $\begin{array}{l}\text { Routine } \\
\text { Visits Only a }\end{array}$ & $\begin{array}{l}\text { Emergency } \\
\text { Visits Only }\end{array}$ & $\begin{array}{l}\text { Mixture } \\
\text { of Visits }\end{array}$ & $\begin{array}{l}\text { Routine } \\
\text { Visits Only }\end{array}$ & $\begin{array}{l}\text { Emergency } \\
\text { Visits Only }\end{array}$ & $\begin{array}{l}\text { Mixture } \\
\text { of Visits }^{c}\end{array}$ \\
\hline \multirow[t]{2}{*}{ Coefficient } & (1) & (2) & (3) & (4) & (5) & (6) \\
\hline & \multicolumn{3}{|c|}{$\begin{array}{l}\text { A. Acute Event Occurred Within One Year of the } \\
\text { Survey }(N=1274)\end{array}$} & \multicolumn{3}{|c|}{$\begin{array}{l}\text { B. Regression Discontinuity at Medicare Eligibility } \\
\text { Threshold }(N=2203)\end{array}$} \\
\hline Private insurance & $\begin{array}{l}12.41^{* *} \\
(6.03)\end{array}$ & $\begin{array}{l}-3.98^{* * *} \\
(1.45)\end{array}$ & $\begin{array}{l}-1.00 \\
(5.63)\end{array}$ & & & \\
\hline Public insurance & $\begin{array}{l}2.66 \\
(6.31)\end{array}$ & $\begin{array}{l}-2.85^{* *} \\
(1.46)\end{array}$ & $\begin{array}{l}13.76^{* * *} \\
(5.51)\end{array}$ & & & \\
\hline \multirow[t]{2}{*}{ RD Term ( $\geq 65)$} & & & & $\begin{array}{l}37.96^{*} \\
(20.73)\end{array}$ & $\begin{array}{l}-61.43^{* *} \\
(27.61)\end{array}$ & $\begin{array}{l}6.44 \\
(7.52)\end{array}$ \\
\hline & \multicolumn{3}{|c|}{ C. Managed Care Effects $(N=36,424)$} & \multicolumn{3}{|c|}{ D. Detailed Coverage Type $(N=36,424)$} \\
\hline Private insurance & $\begin{array}{l}24.24^{* * *} \\
(1.13)\end{array}$ & $\begin{array}{l}-2.16^{* * *} \\
(0.29)\end{array}$ & $\begin{array}{l}1.33^{*} \\
(0.75)\end{array}$ & & & \\
\hline Public insurance & $\begin{array}{l}17.03^{* * *} \\
(1.50)\end{array}$ & $\begin{array}{l}0.20 \\
(0.30)\end{array}$ & $\begin{array}{l}8.17^{* * *} \\
(0.81)\end{array}$ & & & \\
\hline Private insurance $\times$ managed care & $\begin{array}{l}0.28 \\
(0.80)\end{array}$ & $\begin{array}{l}0.11 \\
(0.29)\end{array}$ & $\begin{array}{l}-0.20 \\
(0.48)\end{array}$ & & & \\
\hline Public insurance $\times$ managed care & $\begin{array}{l}2.20 \\
(1.64)\end{array}$ & $\begin{array}{l}0.12 \\
(0.35)\end{array}$ & $\begin{array}{l}0.96 \\
(0.69)\end{array}$ & & & \\
\hline Job-Based Group Insurance & & & & $\begin{array}{l}22.22^{* * *} \\
(0.94)\end{array}$ & $\begin{array}{l}-2.16^{* * *} \\
(0.26)\end{array}$ & $\begin{array}{l}-0.24 \\
(0.55)\end{array}$ \\
\hline Other Group Insurance & & & & $\begin{array}{l}17.24^{* * * *} \\
(4.55)\end{array}$ & $\begin{array}{l}-1.97 \\
(2.38)\end{array}$ & $\begin{array}{l}-1.76 \\
(2.55)\end{array}$ \\
\hline $\begin{array}{l}\text { Individual } \\
\text { (Non-Group) }\end{array}$ & & & & $\begin{array}{l}14.17^{* * *} \\
(1.21)\end{array}$ & $\begin{array}{l}-1.48 \\
(0.33)\end{array}$ & $\begin{array}{l}0.91 \\
(0.67)\end{array}$ \\
\hline Medicaid & & & & $\begin{array}{l}12.56^{* * *} \\
(1.08)\end{array}$ & $\begin{array}{l}0.48^{* *} \\
(0.24)\end{array}$ & $\begin{array}{l}7.89^{* * *} \\
(0.54)\end{array}$ \\
\hline Tricare/CHAMPVA & & & & $\begin{array}{l}1.01 \\
(2.22)\end{array}$ & $\begin{array}{l}1.05^{*} \\
(0.60)\end{array}$ & $\begin{array}{l}2.58^{* *} \\
(1.22)\end{array}$ \\
\hline Other Public & & & & $\begin{array}{l}14.49^{* * *} \\
(5.21)\end{array}$ & $\begin{array}{l}-5.26^{* *} \\
(2.39)\end{array}$ & $\begin{array}{l}-0.30 \\
(2.49)\end{array}$ \\
\hline Uninsured & 1 & 1 & 1 & 1 & 1 & 1 \\
\hline
\end{tabular}

Notes: The multinomial logistic regression coefficients have been converted into marginal effects to improve interpretability. Standard deviations are reported in parentheses. All regressions include individual controls and time trends. The reference category is uninsured respondents

${ }^{a}$ Routine visits only, 2+ routine office based visits only

${ }^{\mathrm{b}}$ Emergency visits only, 2+ emergency room visits only

${ }^{c}$ Mixture of visits, $2+$ routine and emergency room only

* Significant at $10 \%$ confidence level

**Significant at $5 \%$ confidence level

***Significant at $1 \%$ confidence level

emergency rooms are among the most expensive places to seek out care and represent a significant uncompensated care cost to both hospitals and state agencies. Second, privately insured patients have the highest propensity to consume routine office-based visits, while publicly insured patients have the highest propensity to consume a mixture of routine and emergency care. Similar to the uninsured group, the increased propensity of utilizing a mixture of routine and emergency care is likely due to non-price rationing factors that make care accessed through a hospital emergency department more accessible than care sought in the routine office-based setting [17]. When health insurance is decomposed into specific public and private insurance types to control for variations in copayments, deductibles, and gatekeeping, the subgroup analysis demonstrates that the main effects are being driven largely by private group insurance and publicly financed Medicaid insurance.

When modeling patient demand for medical care, studies typically focus their analysis on the effects of individual attributes of health insurance on aggregate measures of healthcare utilization $[1,3,4,18,19]$. There are two drawbacks to this approach regarding understanding how coverage status directly influences health disparities and inequities. First, studies that focus on copayment rates or provider generosity typically focus on understanding how these factors impact service intensity and quality. However, modeling 
differences in service intensity alone will not explain low-value patterns of care use [17]. Second, with an exception to emergency situations, an individual's consumption of medical care is voluntary and driven by price and non-price barriers. Therefore, analysis focused on extensive or intensive margin use of individual services will not reveal patterns of medical services demanded.

There are four main limitations to this paper. First, this study uses repeated cross-section data, which means the evolution of utilization behavior over time cannot be examined. However, this study does examine the timing of diagnosis (Table 5, Panel A) and these results are constant with the main analysis presented in the results. Second, emergency room use is assumed to be voluntary, but it may be the case that patients have no control over their use of the emergency room. This concern was addressed in the design of the medical treatment bundles, where singleton visits only are treated as one or less visits, while the exclusive use of the emergency room to manage their healthcare needs captures a pattern of voluntary use to use the emergency room over other treatments. Third, due to a lack of comprehensive information on disease status and severity, a global disease indicator could not be included as a covariate to control for disease status directly. To overcome this challenge, a subgroup analysis was conducted to include four major chronic diseases: hypertension, coronary heart disease and stroke, diabetes, and cancer. Last, the main results of this study are observational and do not exploit any sources of exogenous variation to explain transitions across insurance states. However, models in this study that use the exogenous variation in the timing of acute health events and an age-based eligibility threshold for Medicare produce results consistent with the main results.

\section{Conclusions}

This paper shows that the insured are more likely to use appropriate levels of medical services than the uninsured. Among the insured, privately insured patients report the highest propensity of using costeffective routine medical care while the publicly insured report the highest propensity to use the least cost-effective mixture of medical services. The analysis contained within this paper demonstrates that these trends not only exist for the overall population, but also across racial/ethnic, major chronic disease subgroup analyses, and alternative/quasi-experiment models. These findings have important implications for the surveillance of inequities in health, understanding the determinants of medical cost growth, the design of utilization incentives for integrated care, and the structure future health insurance coverage expansions should take to generate individual and system-wide cost savings.

\section{Appendix A}

\section{Theoretical Framework}

Patient demand for appropriate medical care is summarized within a random utility model framework, where individuals are assumed to be utility maximizers $[8-10,15]$. There are three types of utility maximizing individuals: an individual with public insurance coverage, an individual with private insurance coverage, and an individual with no insurance coverage. Each type of individual, indexed by $i$, faces a discrete choice decision between $J$ treatment options indexed from $j \in\{O B, E R, M X\}$ : whether to make routine office-based visits only $(O B)$, emergency room visits only $(E R)$, or any mixture of routine officebased visits and emergency room visits $(M X)$.

Each purchase occasion, an individual uses their budgeted income for medical care $y_{i}^{m}$ to select a treatment option $j$ that maximizes their utility. The treatment decision is modeled as follows:

$$
\max _{j, z} U_{i}(H, z) \text { s.t. } p_{j}^{i}+p_{z} z=y_{i}^{m} \text { and } H_{i}=H_{i}\left(x_{j}, \theta_{i}\right)
$$

where $\theta_{i}$ represents pre-treatment health state with larger values indicating worse state of health, $x_{j}$ and characters of treatment bundle $j, p_{j}^{i}$ is the price of treatment bundle $j$ that individual $i$ faces using their insurance, $z$ is an outside option, and $p_{z}$ is the price of the outside option $z . H_{i}(\cdot)$ and $H_{i}$ are the health production function and post-treatment health for individual $i$, respectively.

As $z$ (denoted $j=0$ ) is the non-purchase of any treatment in $J, z$ can be viewed as a fourth treatment option consisting of no medical visits. Alternatively, $z$ can be viewed as some other form of medical investment used to maximize utility. The model assumes $H_{i}(\cdot)$ is differentiable and that the following initial condition holds:

$$
H_{i}\left(0, \theta_{i}\right)=-\theta
$$

This means that if the patient $i$ does not consume a treatment bundle in $J$, then their post-treatment health state is equal to their pre-treatment health state [15].

Substituting the budget constraint into Eq. (1), the patient's problem is now selecting the treatment bundle that gives them the highest conditional indirect utility:

$$
\max _{j} U_{j}\left(H_{i j}\left(x_{i j}, \theta\right), p_{j}, p_{z}, y_{i}^{m}\right)=V_{i j}\left(H_{i j}\left(x_{i j}, \theta\right), p_{j}, p_{z}, y_{i}^{m}\right)+\epsilon_{i j}
$$

where $V_{i j}(\cdot)$ is the indirect utility from all of the 
observable characteristics and $\epsilon_{i j}$ is the unobserved utility that equates $V_{i j}(\cdot)$ to the actual utility of reach individual. An individual treatment bundle is selected if and only if a patient selects a treatment bundle $j$ over all alternative treatment bundles $k \in J$ and $k \neq j$ :

$$
V_{i j}(\cdot)>V_{i k}(\cdot) \forall k \neq j
$$

\section{Empirical Specification}

Following the discrete choice model of demand for medical treatment derived in Appendix A, Section 1, a multinomial logistic regression (MLR) model is used to estimate the probability of selecting an alternative medical treatment bundle based on health insurance type. The probability that an individual $i$ will choose a medical treatment bundle $j$ over $j^{\prime}$ lies between 0 and 1 . The model assumes that individuals select the medical treatment bundle that maximizes their utility [10]. If a linear structure is imposed on the conditional indirect utility function of $i$ (Eq. 3), the model can be expressed as follows:

$$
\operatorname{Pr}\left[Y_{i}=j\right]=\frac{\exp \left(\beta_{j} X_{i}\right)}{\sum_{j=0}^{J} \exp \left(\beta_{j} X_{i}\right)}
$$

where $\operatorname{Pr}\left[Y_{i}=j\right]$ is the probability of choosing either routine visits only, emergency room visits only, or any mixture of routine and emergency room visits, with no medical visits as the reference category. $J$ is the number of treatments in the choice set, $j=0$ is no medical visits, and $\beta_{j}$ and $X_{i}$ are a vector of estimated parameters and independent controls, respectively. If the logit equation above (Eq. 4) is rearranged and exponentiated, the multinomial logistic regression equation used to estimate the coefficients is as follows:

$$
\ln \left[\frac{P_{i}}{1-P_{i}}\right]=b_{0}+b_{1} x_{1}+\ldots+b_{v} x_{v}
$$

From the previous equation (Eq. 5), where $\ln \left[P_{i} /(1-\right.$ $\left.P_{i}\right)$ ], the log odds ratio, is a linear function of independent controls, $X_{i}$. In this paper, the following independent controls are considered: health insurance coverage status, geographic region, race and ethnicity, age in years, gender, educational attainment, and total out-of-pocket expenditures on medical care.

\section{Acknowledgements \\ None.}

\section{Author's contributions}

I am the sole author on the manuscript and responsible for the analysis, reporting, and writing of the quantitative results. The author (s) read and approved the final manuscript.

\section{Funding}

No funding.

\section{Availability of data and materials}

This study uses public-use data from the Medical Expenditure Panel Survey. All data can be found at: https://www.meps.ahrq.gov/mepsweb/index.jsp

\section{Ethics approval and consent to participate}

This study uses public-use secondary data. No ethics approval or consent to participate was required.

\section{Consent for publication}

I am the sole author on this manuscript and I consent to the publication of this manuscript after peer review.

\section{Competing interests}

There are no competing interests.

Received: 30 December 2019 Accepted: 14 September 2020

Published online: 17 September 2020

\section{References}

1. Anderson M, Dobkin C, Gross T. The effect of health insurance coverage on the use of medical services. Am Econ J Econ Policy. 2012;4(1):1-27. https:// www.aeaweb.org/articles?id=10.1257/pol.4.1.1.

2. Ayanian JZ, Weissman JS, Schneider EC, Ginsburg JA, Zaslavsky AM. Unmet health needs of uninsured adults in the United States. JAMA. 2000;284(16): 2061-9.

3. Card D, Dobkin C, Maestas N. The impact of nearly universal insurance coverage on health care utilization: evidence from Medicare. Am Econ Rev. 2008;98(5):2242-58

4. Card D, Dobkin C, Maestas N. DOES MEDICARE SAVE LIVES? Q J Econ. 2009; 124(2):597-636

5. Currie J, Gruber J. Health insurance eligibility, utilization of medical care, and child health. O J Econ. 1996;111(2):431-66.

6. Kronick R. Health insurance coverage and mortality revisited. Health Serv Res. 2009:44(4):1211-31.

7. Lillie-Blanton M, Hoffman C. The role of health insurance coverage in reducing racial/ethnic disparities in health care. Health Aff. 2005;24(2):398408.

8. Aldrich $J \mathrm{H}$, Nelson FD. Quantitative applications in the social sciences: linear probability, logit, and probit models. Thousand Oaks: SAGE Publications, Inc 1984. https://doi.org/10.4135/9781412984744, https://methods.sagepub. com/book/linear-probability-logit-and-probit-models.

9. Gertler P, Locay L, Sanderson W. Are user fees regressive?: the welfare implications of health care financing proposals in Peru. J Econ. 1987;36(1-2): 67-88.

10. McFadden DL. Conditional Logit Analysis of Qualitative Choice Behavior. In: Zarembka P, editor. Frontiers in Econometrics. New York: Academic Press; 1973. p. 105-42.

11. McFadden DL. Qualitative Response Models. In: Hildenbrand W, editor. Advances in Econometrics. Cambridge: Cambridge University Press; 1983. p. 1-38.

12. D'Agostino RB, Vasan RS, Pencina MJ, Wolf PA, Cobain M, Massaro JM, Kannel WB. General cardiovascular risk profile for use in primary care: the Framingham heart study. Circulation. 2008;117(6):743-53.

13. Dugan J, Virani SS, Ho V. Medicare eligibility and physician utilization among adults with coronary heart disease and stroke. Med Care. 2012;50(6): 547-53.

14. Kim AS, Claiborne Johnston S. Global variation in the relative burden of stroke and ischemic heart disease. Circulation. 2011;124(3):314-23.

15. Brand, Keith. 2005. "A Structural Model of Health Plan Choice and Health Care Demand in the Medicare Managed Care Program." Unpublished Ph. D. Dissertation, University of Virginia.[86].

16. Reinhardt UE. Rationing health care: what it is, what it is not, and why cannot avoid it. Baxter Health Policy Rev. 1996;2:63-99.

17. Kangovi S, Barg FK, Carter T, Long JA, Shannon R, Grande D. Understanding why patients of low socioeconomic status prefer hospitals over ambulatory care. Health Aff. 2013;32(7):1196-203.

18. Aron-Dine A, Einav L, Finkelstein A. The RAND health insurance experiment, three decades later. J Econ Perspect. 2013;27(1):197-222. 
19. Dor A, Farley DE. Payment source and the cost of hospital care: evidence from a multiproduct cost function with multiple payers. J Health Econ 1996;15(1):1-21.

\section{Publisher's Note}

Springer Nature remains neutral with regard to jurisdictional claims in published maps and institutional affiliations.

Ready to submit your research? Choose BMC and benefit from:

- fast, convenient online submission

- thorough peer review by experienced researchers in your field

- rapid publication on acceptance

- support for research data, including large and complex data types

- gold Open Access which fosters wider collaboration and increased citations

- maximum visibility for your research: over $100 \mathrm{M}$ website views per year

At BMC, research is always in progress. 